\title{
Morphology and life history studies of Endarachne binghamiae (Scytosiphonaceae, Phaeophyta) from the Azores
}

\author{
Manuela I. Parente ${ }^{a}$, Ana I. Neto ${ }^{a}, *$, Rober L. Fletcher ${ }^{b}$ \\ a Secção de Biologia Marinha, Departamento de Biologia, Universidade dos Açores, \\ Rua da Mãe de Deus, 9500 Ponta Delgada, Azores, Portugal \\ ${ }^{\mathrm{b}}$ University of Portsmouth, Institute of Marine Sciences, Ferry Road, Eastney, \\ Portsmouth, Hampshire PO4 9LY, UK
}

Received 13 June 2002; received in revised form 12 December 2002; accepted 3 February 2003

\begin{abstract}
First reported for the Azores in 1994, Endarachne binghamiae is commonly found throughout the year on hard substrates in the upper mid-tidal region of the exposed Azorean shores. Morphological and culture studies of this species were carried out based on material collected from six localities on the island of São Miguel. Erect thalli collected in the field are dorsiventrally flattened and arise from an encrusting base or small discoid holdfast. The erect blades, up to $13 \mathrm{~cm}$ long and $2 \mathrm{~cm}$ wide, are lanceolate or obovate, simple, solid and thin, gradually tapering at the base. The plurilocular sporangia lack paraphyses and are positioned in continuous sori covering most of the surface area of the blades. Reproductive plants, with plurilocular sporangia, occurred all year round. In culture, spores released from the plurilocular sporangia developed into small knot-filaments, which upon squashing exhibited a three-dimensional representation of a typical multistratose crust. These prostrate knot-filaments gave rise directly to new erect blades. No unilocular sporangia were seen and no evidence of sexuality was observed. These results are similar to those reported of Californian plants, indicating that the Azorean Endarachne have a monophasic heteromorphic life history. (C) 2003 Elsevier Science B.V. All rights reserved.
\end{abstract}

Keywords: Endarachne binghamiae; Life history; Phaeophyta; Phenology; Scytosiphonaceae

\section{Introduction}

Endarachne binghamiae J. Agardh is monotypic. It was originally described in 1896, based on material collected from the vicinity of Santa Barbara, CA (Wynne, 1969), where

\footnotetext{
* Corresponding author. Tel.: +35-1296-650000; fax: +35-1296-650100.

E-mail address: aneto@notes.uac.pt (A.I. Neto).
} 
it is a common species (Setchell and Gardner, 1925; Abbott and Hollenberg, 1976). It is distributed in the warmer waters of the northern and southern Pacific Ocean and in the Indian Ocean, namely China, Japan, Australia (Nizamuddin and Farooqi, 1968), South Africa (Nizamuddin and Farooqi, 1968; Silva et al., 1996) and Saint Helena (Lawson et al., 1993). In the Azores, this species was first collected from Terceira by Fralick in 1980, but only recently was reported in Faial and Pico by Tittley and Neto (1994) and in São Miguel by Neto (2000). Surprisingly, it has not been reported for the Canary Islands, Madeira or the West African coast, with the Azores representing its only locality in the North Atlantic. It is possible, therefore, that the species is introduced (Tittley and Neto, 1994).

E. binghamiae is characterised by solid and unbranched erect blades with a medulla consisting of intertwining medullary filaments. The habit is very similar to Petalonia, but the latter has a medulla composed of more or less isodiametric cells. Setchell and Gardner (1925) noted, however, that in Petalonia the central cells of the medulla are, sometimes, more or less elongated. Later, Vinogradova (1973 fide Silva et al., 1996) found a conspicuous development of filaments in the medulla of $P$. zosterifolia from Siberia, and merged Endarachne with Petalonia. In the present study, as in Silva et al. (1996), the genus Endarachne is retained, pending further studies.

Life history studies of E. binghamiae (Kunieda and Suto, 1948; Nakamura and Tatewaki, 1975), reported the presence of isogamy, and no significant differences in motility were reported between female and male gametes. Nakamura and Tatewaki (1975), working with material from Japan, reported the occurrence of gametic fusion and unfused gametes that developed parthenogenetically. They also reported a crustose microthallus phase in the life history of this species, and observed a sexual cycle with an alternation of heteromorphic generations in the plants studied. Crusts, with unilocular sporangia, were the result of zygotes and parthenogametic development. In contrast, Wynne (1969) working with Californian material, only reported the presence of asexual reproductive spores released from plurilocular sporangia (termed zooids).

The present study was initiated to obtain information on the morphology and ecology of E. binghamiae from the Azores and to undertake laboratory culture studies to determine if it has a microthallus stage in its life history similar to that reported elsewhere.

\section{Materials and methods}

The island of São Miguel is the largest of the archipelago of the Azores, located between the coordinates $37-40^{\circ} \mathrm{N}$ and $25-31^{\circ} \mathrm{W}$ (see Neto et al., 2002). Research was undertaken in the period between May 1998 and May 1999 at seven sites distributed around the island, three on the southern coast (Feteiras, Pópulo, Caloura), three on the northern coast (Maia, Calhetas, São Vicente) and one on the western coast (Mosteiros). The field methodology involved monthly sampling at the intertidal zone of the study sites. Additional collections to provide material for the unialgal cultures were made until May 2001.

In the laboratory, the specimens were examined using a combination of stereo and compound microscopes. The specimens were numbered (SMG-97-345; SMG-98-16; SMG-9829; SMG-98-63; SMG-98-218; SMG-98-526; SMG-98-863a; SMG-99-17; SMG-99-458; SMG-99-787) and a reference collection was made by storing the algae in a $5 \%$ buffered 
formaldehyde-seawater solution. All collections were deposited at the Department of Biology of the University of the Azores. The systematic organization and nomenclatural synopsis used in this study generally follows that adopted by Silva et al. (1996). Whenever necessary, the entire thallus, portions or sections of it were observed microscopically. Sections were obtained with a freezing microtome. Measurements of cells and other structures were made using a micrometer eye piece. A representative collection of colour slides was made using an OLYMPUS-PM 10-35 AD-1 microphotography system. Camera lucida drawings were also made.

For the life history investigations, a number of laboratory culture studies were undertaken. Two growing cabinets providing two different environmental regimes (regime 1: $15^{\circ} \mathrm{C}$; 8-16 h light-dark; regime $2: 22^{\circ} \mathrm{C} ; 16-8 \mathrm{~h}$ light-dark) were used in the culture studies. The chosen regimes corresponded approximately to intertidal conditions in winter and summer at São Miguel. The culture medium used in these studies was that of Grund (von Stosch, 1964). After collection from the field, the algae were washed in clean seawater and the surface wiped clean with small portions of cotton wool, to remove any epiphytes and prepare the material for spore release. The isolation technique employed in this study follows Wynne (1969).

Unialgal cultures were started from spores of plurilocular sporangia of plants collected in São Vicente (July 1998, March and April 1999), Mosteiros (March 1999), Maia (April 1999) and Pópulo (April 1999, February and March 2001). Eighteen plants were used with a minimum of four replicates, and distributed in culture regimes 1 and 2. Cultures were examined every 5 days using an inverted compound microscope. For microscope observations, cover slips with attached germlings were placed on a glass slide. A fresh cover slip was placed over the surface of the slip with the germlings to prevent their desiccation. This method was used for microphotography of the developing stages of the germlings. When a subsequent generation was required, fertile material was subcultured by using this same hanging-drop method.

\section{Results}

\subsection{Morphology and phenology}

Plants formed erect, dorsiventrally flattened blades that arose from an encrusting base or small discoid holdfast. The erect blades were lanceolate or obovate, simple, solid and thin, up to $13 \mathrm{~cm}$ long and $2 \mathrm{~cm}$ wide, gradually tapering at the base (Fig. 1A). In surface view, the cells were irregularly arranged, rectangular to polygonal in shape, 5-11 $\mu \mathrm{m}$ in diameter, and with a single, plate-like, parietal plastid containing one pyrenoid. In section (Fig. 1B), blades were up to $269 \mu \mathrm{m}$ thick comprising two-three layers of outer pigmented cortical cells and an inner medulla comprising intertwined branched filaments. Outer cortical cells measured 7-9 $\mu \mathrm{m} \times 4-6 \mu \mathrm{m}$ whilst inner cortical cells measured 7-9 $\mu \mathrm{m} \times 5-7 \mu \mathrm{m}$. Hairs were common, 5-6 $\mu \mathrm{m}$ in diameter, organized in fascicles and arising from the cortical cells. Plurilocular sporangia, lacking paraphyses, were positioned in continuous sori covering most of the surface area of the blades (Fig. 1B and C). Sporangia (17-43 $\mu \mathrm{m} \times 4-8 \mu \mathrm{m}$ ) were commonly uniseriate, sometimes biseriate and formed up to 11 subquadrate to rectangular 


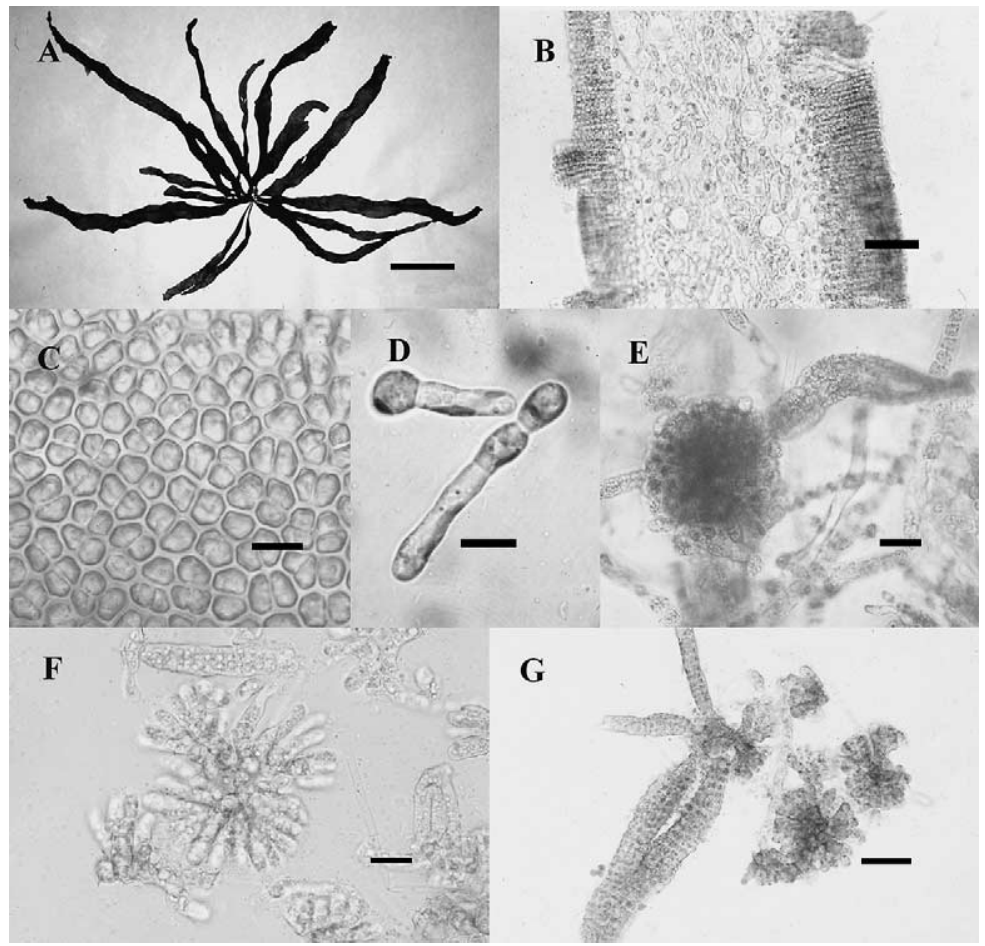

Fig. 1. E. binghamiae (A-C) plant collected in the field; (D-G) culture development: (A) habit, bar $=5 \mathrm{~cm}$; (B) section of mature thallus bearing plurilocular sporangia, bar $=50 \mu \mathrm{m}$; (C) surface view of erect thallus with plurilocular sporangia, bar $=10 \mu \mathrm{m}$; (D) 3-day-old germlings, bar $=10 \mu \mathrm{m}$; (E) knot-ball filament, bar $=20 \mu \mathrm{m}$; (F) squash of knot-filament, bar $=20 \mu \mathrm{m}$; (G) erect blade emerging from squashed knot-filament, bar $=50 \mu \mathrm{m}$.

loculi, each measuring 4-6 $\mu \mathrm{m} \times 4-5 \mu \mathrm{m}$. Unilocular sporangia were not observed and are unknown on the erect thallus.

Plants were common at all sites visited except Caloura, occurring year round, on large stones, bedrock and other hard substrates in the upper mid-tidal region. Reproductive plants, with plurilocular sporangia, were collected from January to July. Associated species included Caulacanthus ustulatus (Turner) Kützing, Chondracanthus acicularis (Roth) Fredericq, Corallina elongata J. Ellis et Solander, Enteromorpha intestinalis (L.) Link, Halopteris filicina (Grateloup) Kützing, Stypocaulon scoparia (Linné) Kützing and Ulva rigida C. Agardh.

\subsection{Life history studies}

\subsubsection{Early development}

The spores released from the plurilocular sporangia were pyriform in shape, and each had a parietal, plate-like plastid with a prominent red eye spot. After 3-4h, they stopped swimming and attached to the cover slip. After spore settlement, a number of cultures were 
set up and distributed into culture regimes 1 and 2. Within 1-2 days, all spores developed small germ tubes. After 3-5 days, the germlings divided into two-three cells (Fig. 1D). Within 5-10 days, approximately all germlings were filamentous with 10 or more cells and each germling developed a true hair.

\subsubsection{Development of knot-balls/knot-filaments}

Some germlings continued development to form larger filaments, and then divided up to produce a knot of tissue (Fig. 1E). This knot developed along the filament length and remained attached to it (knot-filaments) or rounded off and became free (knot-balls). The knot-filaments were formed by a series of periclinal divisions in the main axial cells of the filament. Knot-balls were similar to knot-filaments but were free and normally bigger. Cells of knot-filaments and knot-balls continued dividing and developed new rows of cells outwardly. When squashed (Fig. 1F), these structures showed a central base with radial erect filaments up to five cells long, revealing a pseudoparenchymatous mode of construction typical of a crust. Each cell contained one large parietal, plate-like plastid with one-two pyrenoids. Both knot-filaments and knot-balls developed numerous hairs and were difficult to squash.

\subsubsection{Development of small discs}

Some initial germling filaments became strongly adherent to the substratum and developed to form small monostromatic discs. These differed from real crusts in that they did not form confluent apical cells necessary to develop true crustose thalli. From the main axis and outwardly spreading monostromatic layer of these small discs, many erect filaments emerged.



Fig. 2. Diagrammatic illustration of the life history of Azorean E. binghamiae. (1) Macrothallus with plurilocular sporangia. (2) Transversal section of a small portion of macrothallus with plurilocular sporangia. (3) Spore from the plurilocular sporangia (plurispore). (4) Disc with erect blades emerging. H, True hair; MA, macrothallus; MI, microthallus; PS, plurilocular sporangia. 


\subsubsection{Development of erect blades}

Erect blades were produced abundantly in cultures from knot-filaments, knot-balls and discs and were the result of extensions of the upper cells of these structures. A serious of transverse and longitudinal divisions on these small, erect filaments produced parenchymatous blades (Fig. 1G). These were flattened and, a large number of small secondary blades emerged from each. Blades were composed of two layers of cortical cells and a filamentous medulla. After 3-4 months, plurilocular sporangia developed on their surface.

In cultures under both regimes, the majority of germlings formed knot-filaments and knot-balls. Only some cultures under regime 2 developed discs. Erect blades were produced in both regimes, from the above range of morphological types. All cultures under regime 2 conditions tended to develop more quickly, but the development did not appear to be strongly influenced by any particular regime. The present results indicated the occurrence of a monophasic and heteromorphic life history for E. binghamiae in the Azores (Fig. 2), where this species was revealed to have a pseudoparenchymatous microthallus without reproductive organs. Spores from the plurilocular sporangia of the erect thalli germinated directly, without sexual fusion to repeat the parental thallus, the blade form.

\section{Discussion}

The Azorean material agrees well with the description given for Californian plants by Agardh (1870) and Abbott and Hollenberg (1976).

Despite its greater abundance in spring, the widespread seasonal occurrence of this species observed in the present investigation agrees with previous results obtained by Neto (2000), who reported the occurrence of reproductive specimens of this species in January, March, July, September and November. E. binghamiae has been recognised as an opportunistic alga by Littler and Littler (1980), a description given to organisms characterised by simple thalli (normally sheet-like), with a large surface to volume ratio, rapid growth rates and high productivity. Opportunistic algae are also known to produce large numbers of spores over extensive periods, while late successional species are characterised by more marked seasonal variability and the release of small numbers of propagules (Littler and Littler, 1980). According to these authors, E. binghamiae is also an early coloniser of disturbed intertidal substrata. Our observations confirm these generalisations from western America. The decrease in abundance observed in the winter months was also observed by Neto (2000) and is probably related to the higher wave action that occurs in this season. Plants are ripped from rocks by erosion, and the combined accelerational and drag forces caused by wave action (Gaylord et al., 1994). Winter is also the period of the year in which the effect of the wind is stronger (Instituto Hidrográfico, 1981) and both the seawater temperature and the number of hours of light are lower.

The culture studies suggested the occurrence of a monophasic and heteromorphic life history. Similar results have been obtained by Wynne (1969), with a single difference. He reported the formation of germlings that developed into discoid holdfasts giving rise to new blades. In Azorean cultures, not only holdfasts have been formed, but also knot-filaments. When these latter structures were squashed, they showed a central base with radial erect filaments that seemed to be a three-dimensional representation of a crust, which indicates 
that a crustose stage is possibly implicated in the life history of Azorean E. binghamiae. Interestingly, Nakamura and Tatewaki (1975) observed a sexual cycle with an alternation of heteromorphic generations in plants from Japan. Crusts, with unilocular sporangia, were the result of zygotic and parthenogametic development. It might well be that under a particular set of conditions, this species might alternatively be capable of forming a crust. The presence or absence of a crustose stage in the Scytosiphonaceae can, in fact, be influenced by environmental conditions. Lüning and Dring (1973) observed that light quality influenced the morphological expression of some members of Scytosiphonaceae (Scytosiphon lomentaria, Petalonia fascia, P. zosterifolia). Many studies (Edwards, 1969; Fletcher, 1978; Nakamura and Tatewaki, 1975) have shown that the combination of photoperiod/day length and temperature determine the morphogenetic responses with respect to the production of either crustose or erect-bladed thalli. No obvious difference was observed in the size, colour, motility and behaviour of the reproductive spores released from the plurilocular sporangia. The same was observed by Nakamura and Tatewaki (1975) and Kunieda and Suto (1948). The former authors reported the occurrence of gametic fusion and unfused gametes that developed parthenogenetically whereas Wynne (1969) working with Californian material only reported the presence of asexual reproductive spores released from plurilocular sporangia.

Because of the practical difficulties in distinguishing sexual from asexual plants, and because mixed cultures of different thalli were not set up in the present study, it is premature to speculate whether sexual reproduction occurs in Azorean E. binghamiae. Hence we cannot resolve the contrast between Wynne's (1969) observations and those of Nakamura and Tatewaki (1975) for Atlantic E. binghamiae.

\section{Acknowledgements}

We are grateful to Dr. Rui Sousa, Sandra C. Monteiro and Patrícia Pereira, for helping with collections and culture work. Dr. Marlene Terra is acknowledged for providing the drawing of Fig. 2. The present research is part of a larger investigation undertaken as requirement for a masters degree in the University of Portsmouth.

\section{References}

Abbott, I.A., Hollenberg, G.J., 1976. Marine Algae of California, vol. xii. Stanford University Press, Stanford, CA, p. 827, pp. 200-202.

Agardh, J.G., 1870. Om de under Korvetten Josephines expedition, sistliden sommar, insamlade Algerna. Översigt af Kungl. Vetenskaps-Akademiens Förhandlingar 4, 359-366.

Edwards, P., 1969. Field and cultural studies on the seasonal periodicity of growth and reproduction of selected Texas benthic marine algae. Contr. Mar. Sci. Univ. Tex. 14, 59-114.

Fletcher, R.L., 1978. Studies on the family Ralfsiaceae (Phaeophyta) around the British Isles. In: Irvine, D.E.G., Price, J.H. (Eds.), Modern Approaches to the Taxonomy of Red and Brown Algae, Systematics Association Special, vol. 10. Academic Press, London, pp. 371-398.

Gaylord, B., Blanchette, C.A., Denny, M.W., 1994. Mechanical consequences of size in waveswept algae. Ecol. Monogr. 64, 287-313.

Instituto Hidrográfico, 1981. Roteiro do Arquipélago dos Açores, PUB: (N)-IH-128-SN. Lisboa.

Kunieda, H., Suto, S., 1948. On the isogamy and the life history of Endarachne binghamiae and Colpomenia bullosa. Suis. Ho 10, 8-9. 
Lawson, G.W., John, D.M., Price, J.H., 1993. The marine algal flora of St. Helena: its distribution and biogeographical affinities. Courier Forschungs-Institut Senckenberg 159, 103-107.

Littler, M.M., Littler, D.S., 1980. The evolution of thallus form and survival strategies in benthic marine macroalgae: field and laboratory tests of a functional form model. Am. Nat. 116, 25-44.

Lüning, K., Dring, M.J., 1973. The influence of light quantity on the development of the brown algae Petalonia and Scytosiphon. Br. Phycol. J. 8, 333-338.

Nakamura, Y., Tatewaki, M., 1975. The life history of some species of the Scytosiphonales. Sci. Pap. Ins. Algol. Res. Hokkaido Univ. 6, 57-93.

Neto, A.I., 2000. Observations on the biology and ecology of selected macroalgae from the littoral of São Miguel (Azores). Bot. Mar. 43, 483-498.

Neto, A.I., Terra, M.R., Haroun, R.J., 2002. New foliose and gelatinous red macroalgae (Rhodophycota) from the Azores: morphological and geographical observations. Aquat. Bot. 72, 1-11.

Nizamuddin, M., Farooqi, P.B., 1968. The morphology and structure of Endarachne binghamiae. J. Agardh. Bot. Mar. 11, 40-53.

Setchell, W.A., Gardner, N.L., 1925. The marine algae of the Pacific coast of North America. Part III. Melanophyceae. Univ. Calif. Publs. Bot. 8, 383-898.

Silva, P.C., Basson, P.W., Moe, R.L., 1996. Catalogue of the benthic marine algae of the Indian Ocean. Univ. Calif. Publs. Bot. 79, 1259

Tittley, I., Neto, A.I., 1994. Expedition Azores (1989). Benthic marine algae (seaweeds) recorded from Faial and Pico. Arquipelago. Life Mar. Sci. 12A, 1-13.

von Stosch, H.A., 1964. Wirkungen von Jod und Arsenit auf Meeresalgen in Kultur. In: DeVirville, D., Feldmann, J. (Eds.), Proceedings of the Fourth International Seaweed Symposium. Pergamon Press, Oxford, pp. 142-150.

Wynne, M.J., 1969. Life history and systematic studies of some Pacific North American Phaeophyceae (brown algae). Univ. Calif. Publs. Bot. 50, 1-88. 